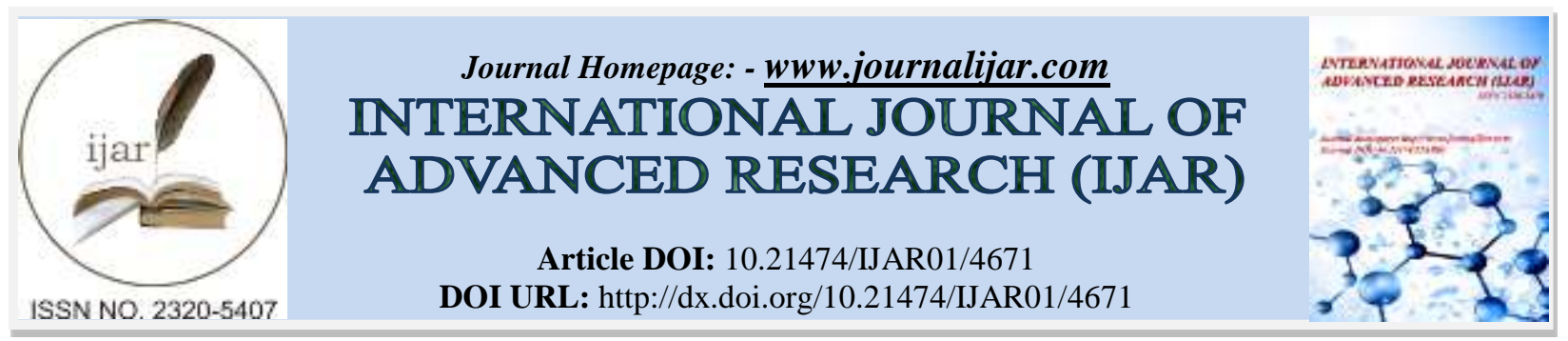

RESEARCH ARTICLE

\title{
NUTRITIONAL COMPOSITION OF SPIRULINA PLATENSIS POWDER AND ITS ACCEPTABILITY IN FOOD PRODUCTS.
}

Vatsala Saharan* And Sudesh Jood.

Dept. of Foods and Nutrition, College of Home Science, CCS Haryana Agricultural University, Hisar-125004, India

\section{Manuscript Info}

Manuscript History

Received: 22 April 2017

Final Accepted: 26 May 2017

Published: June 2017

Key words:-

Spirulina platensis powder, nutritional composition, fatty acid profile, food products, acceptability

\section{Abstract}

The aim of the present study was to evaluate the physico-chemical properties of Spirulina platensis powder and its incorporation in wheat flour for development of value added products and their consumer acceptability. Spirulina was found to be very rich source of protein i.e $71.90 \%$ with high in vitro digestibility $(92.59 \%)$ and containing all essential amino acids specially total lysine $(5.72 \mathrm{~g} / 16 \mathrm{gN})$ as this amino acid is lacking in wheat flour. It also contained good amount of crude fibre $(9.70 \%)$, ash $(3.50 \%)$ and total dietary fibre (14.98\%), whereas, carbohydrate $(13.63 \%)$ and fat $(1.27 \%)$ were found to be in very low amount which contributed low energy $(353.55 \mathrm{Kcal} / 100 \mathrm{~g})$ content. With regard to total minerals such as calcium, phosphorus, magnesium, iron and zinc were 620.80, 790.42, 285.90, 49.50 and $3.95 \mathrm{mg} / 100 \mathrm{~g}$, respectively were reported in Spirulina platensis powder. $\alpha$ - linolenic and $\gamma$-linolenic acid which accounted for 14.80 and $30.00 \%$ of total fatty acids, respectively were reported in Spirulina powder. Hence, keeping in view its excellent nutritional profile, Spirulina powder was incorporated at different levels i.e 2, 4, 6 and $8 \%$ in wheat flour for development of biscuits, buns, noodles and macroni and evaluated for their consumer acceptability. It was observed that all the products up to $6 \%$ level of incorporation were found acceptable by majority of respondents.

Copy Right, IJAR, 2017,. All rights reserved.

\section{Introduction:-}

In India the problems of protein energy malnutrition, anemia, and vitamin A deficiency are more prevalent among children and adolescents (Udayasree et al., 2013). To overcome these problems, the need of nutrient rich foods came into existence. One of such foods which constitute the most remarkable concentration of nutrients is "Spirulina". Spirulina, which is commercially known as Arthospira, is one of blue-green algae due to presence of chlorophyll, carotenoid and phycocyanin pigments. It is a simple one celled form of algae that thrives in warm, alkaline freshwater bodies (Devinamerin et al., 2007; Navacchi et al., 2012; Vijayarani et al., 2012). Spirulina is the common name for human and animal food supplements produced primarily from two species of Cyanobacteria i.e. Arthrospira platensis and Arthrospira maxima. Spirulina platensis is commonly produced and cultivated in Asian countries particularly in India, Japan and China whereas Spirulina maxima production is mainly confined to Central America (Moorhead et al., 2011).

\section{Corresponding Author:- Vatsala Saharan.}


Countless beneficial effects of Spirulina attributed due to its high nutritional value and bioactive compounds, vitamins and polyunsaturated fatty acids including the gamma-linolenic and linoleic acids (Devinamerin et al., 2007). It has many therapeutic properties such as hypocholesterolemic, immunological, antiviral and antiglutagenic effects (McCarty, 2007). It is an excellent source of good quality protein (60-70\%) with all essential amino acids in perfect balance and also provide high concentration of minerals and $\mathrm{B}$-complex vitamins specially vitamin $\mathrm{B}_{12}$ which is usually found in animal tissues (Devinamerin et al., 2007; Vijayarani et al., 2012). Spirulina supplements are available in powder, flakes, capsule and tablet forms. In spite of being highly nutrient-rich, its use is still restricted in food products. Therefore, utilization of nutrient-rich Spirulina powder in development of food products may be encouraged to improve the nutritional status of the general population. Keeping these facts in view, an attempt has been made to analyze nutrient composition of Spirulina powder and to explore the use of nutrient dense Spirulina powder in development of bakery and pasta products and their consumer acceptability.

\section{Materials And Methods:-}

Procurement of raw Materials:-

Spirulina platensis powder was purchased from Herbo Nutra, Wholesale Trader from New Delhi. Wheat variety (WH-1105) was procured from Wheat and Barley Section of Department of Genetics and Plant Breeding, CCSHAU, Hisar. Other ingredients were purchased from local market.

\section{Nutritional Composition:-}

Proximate composition, carbohydrate and energy:-

Moisture, protein, fat, crude fiber, ash were estimated by standard method of analysis (AOAC, 2000). Total carbohydrates was estimated by calculation method as given:

Total carbohydrate $(\%)=100-$ [crude protein + crude fat + crude fibre + ash]

Total energy was calculated theoretically by using the following conversion factors $4.0,4.0$ and $9.0 \mathrm{kcal} / 100 \mathrm{~g}$ for protein, carbohydrates and fat, respectively according to the method described by Paul and Southgate (1979).

\section{In vitro protein digestibility and total lysine:-}

In vitro protein digestibility was carried out by using the modified method of Mertz et al. (1983). Total lysine was estimated as per the method described by Mertz et al. (1975).

\section{Dietary fibre, total minerals and fatty acid profile:-}

Total, soluble and insoluble dietary fibre constituents were determined by the enzymatic method given by Furda (1981). The sum of insoluble dietary fibre and soluble dietary fibre contents were calculated as total dietary fibre. The samples were wet acid-digested using a nitric acid and perchloric acid mixture $\left(\mathrm{HNO}_{3}: \mathrm{HClO}_{4}:: 5: 1\right.$, w/v). The total amount of calcium, magnesium, iron and zinc in acid digested samples were determined by Atomic Absorption Spectrophotometer according to the method of Lindsey and Norwell (1969). Whereas, phosphorus was determined colorimetrically by using the method of Chen et al. (1956). Fatty acid profile of Spirulina platensispowder was determined by the method of gas liquid chromatography (Vasudev et. al., 2008).

\section{Development of products:-}

Various products like biscuits, buns, noodles and macroni were developed by using 2, 4, 6 and $8 \%$ level of Spirulina powder in wheat flour along with their respective control products.

\section{Selection of panel Members:-}

For carrying out organoleptic acceptability of the developed products, a panel of 20 judges were selected from college of Home Science CCS Haryana Agriculture University, Hisar. The selected subjects were in the age group of $20-40$ years.

\section{Organoleptic acceptability of developed products:-}

Various products like biscuits, buns, noodles and macroni were developed using standard recipes by incorporation of Spirulina platensis powder at 2, 4,6 and $8 \%$ levels in wheat flour along with their respective control products. All the products like biscuits, buns, noodles and macroni were evaluated by the 20 panelists for their acceptability using Hedonic Scoring Technique. The method is actually a measure of acceptability gauged from the reaction in terms of their degree of like or dislikes for a given product. The reactions are indicated by descriptions in words on a scale for e.g ranging from 'liked extremely' (9) to 'disliked extremely' (1). 
Table 1:- Proximate composition, in vitro protein digestibility and total lysine of Spirulina platensis powder (on dry matter basis)

\begin{tabular}{|c|c|}
\hline Parameters & Spirulina platensis powder \\
\hline Moisture (\%) & $5.27 \pm 0.12$ \\
\hline Protein (\%) & $71.90 \pm 3.35$ \\
\hline Fat (\%) & $1.27 \pm 0.08$ \\
\hline Crude fibre (\%) & $9.70 \pm 1.20$ \\
\hline Ash (\%) & $3.50 \pm 0.36$ \\
\hline Carbohydrates (\%) & $13.63 \pm 1.15$ \\
\hline Energy (Kcal/100g) & $353.55 \pm 3.42$ \\
\hline In vitro protein digestibility (\%) & $92.59 \pm 0.85$ \\
\hline Total lysine (g/16gN) & $5.72 \pm 0.49$ \\
\hline
\end{tabular}

Table 2:- Dietary fibre (\%) and total mineral (mg/100g) contents of Spirulina platensis powder (on dry matter basis)

\begin{tabular}{|c|c|}
\hline Parameters & Spirulina platensis powder \\
\hline Total dietary fibre & $14.98 \pm 1.11$ \\
\hline Soluble dietary fibre & $5.52 \pm 0.91$ \\
\hline Insoluble dietary fibre & $9.46 \pm 1.26$ \\
\hline Calcium & $620.80 \pm 11.22$ \\
\hline Phosphorus & $790.42 \pm 9.00$ \\
\hline Magnesium & $285.90 \pm 8.28$ \\
\hline Iron & $49.50 \pm 6.61$ \\
\hline Zinc & $3.95 \pm 0.29$ \\
\hline
\end{tabular}

Table 3:- Fatty acid profile of Spirulina platensis powder

\begin{tabular}{|c|c|}
\hline Fatty acid profile (\% of total fatty acids) \\
\hline Palmitic & $30.50 \pm 3.52$ \\
\hline Stearic & $1.90 \pm 0.09$ \\
\hline Oleic & $10.60 \pm 1.12$ \\
\hline Linoleic (omega-6) & $2.50 \pm 0.08$ \\
\hline Alpha-linolenic (omega-3) & $14.80 \pm 2.03$ \\
\hline Gamma-linolenic (omega-6) & $30.00 \pm 2.58$ \\
\hline
\end{tabular}

Table 4:- Percentage of acceptability scores of biscuits and buns by the respondents $(n=20)$

\begin{tabular}{|c|c|c|c|c|c|c|c|c|c|}
\hline Products & $\begin{array}{c}\text { Liked } \\
\text { extremely } \\
\text { (9) }\end{array}$ & $\begin{array}{c}\text { Liked } \\
\text { Very } \\
\text { much } \\
(8)\end{array}$ & $\begin{array}{c}\text { Liked } \\
\text { Moderately } \\
\text { (7) }\end{array}$ & $\begin{array}{c}\text { Liked } \\
\text { Slightly } \\
\text { (6) }\end{array}$ & $\begin{array}{c}\text { Neither } \\
\text { liked nor } \\
\text { disliked } \\
(5)\end{array}$ & $\begin{array}{c}\text { Disliked } \\
\text { slightly } \\
\text { (4) }\end{array}$ & $\begin{array}{c}\text { Disliked } \\
\text { moderately } \\
(3)\end{array}$ & $\begin{array}{c}\text { Disliked } \\
\text { very } \\
\text { much } \\
(2)\end{array}$ & $\begin{array}{r}\text { Disliked } \\
\text { extremely } \\
(1)\end{array}$ \\
\hline \multicolumn{10}{|l|}{ Biscuits } \\
\hline Control & $2(10)$ & $2(10)$ & $14(70)$ & $2(10)$ & - & - & - & - & - \\
\hline \multicolumn{10}{|l|}{ Supplemented } \\
\hline $2 \%$ & $2(10)$ & $3(15)$ & $14(70)$ & $1(5)$ & - & - & - & - & - \\
\hline $4 \%$ & - & $2(10)$ & $12(60)$ & $6(30)$ & - & - & - & - & - \\
\hline $6 \%$ & - & - & $14(70)$ & $6(30)$ & - & - & - & - & - \\
\hline $8 \%$ & - & - & $2(10)$ & $12(60)$ & $6(30)$ & - & - & - & - \\
\hline \multicolumn{10}{|l|}{ Buns } \\
\hline Control & $2(10)$ & $6(30)$ & $10(50)$ & $2(10)$ & - & - & - & - & - \\
\hline \multicolumn{10}{|l|}{ supplemented } \\
\hline $2 \%$ & $3(15)$ & $6(30)$ & $10(50)$ & $1(5)$ & - & - & - & - & - \\
\hline $4 \%$ & - & $6(30)$ & $10(50)$ & $2(10)$ & $2(10)$ & - & - & - & - \\
\hline $6 \%$ & - & - & $15(75)$ & $4(20)$ & $1(5)$ & - & - & - & - \\
\hline $8 \%$ & - & - & $2(10)$ & $12(60)$ & $6(30)$ & - & - & - & - \\
\hline
\end{tabular}

Figures outside parentheses indicate number of respondents

Values in parentheses are percentage 
Table 5:- Percentage of acceptability scores of noodles and macroni by the respondents $(\mathrm{n}=20)$

\begin{tabular}{|c|c|c|c|c|c|c|c|c|c|}
\hline $\begin{array}{l}\text { Product } \\
\text { s }\end{array}$ & $\begin{array}{c}\text { Liked } \\
\text { extremely } \\
\text { (9) }\end{array}$ & $\begin{array}{c}\text { Liked } \\
\text { Very } \\
\text { much } \\
(8) \\
\end{array}$ & $\begin{array}{c}\text { Liked } \\
\text { Modera } \\
\text { tely } \\
(7) \\
\end{array}$ & $\begin{array}{c}\text { Liked } \\
\text { Slightl } \\
\mathbf{y} \\
(6) \\
\end{array}$ & $\begin{array}{c}\text { Neither } \\
\text { liked nor } \\
\text { disliked } \\
(5)\end{array}$ & $\begin{array}{c}\text { Dislike } \\
\text { d } \\
\text { slightly } \\
(4)\end{array}$ & $\begin{array}{c}\text { Disliked } \\
\text { moderat } \\
\text { ely } \\
(3) \\
\end{array}$ & $\begin{array}{c}\text { Dislike } \\
\text { d very } \\
\text { much } \\
(2) \\
\end{array}$ & $\begin{array}{c}\text { Disliked } \\
\text { extremel } \\
y \\
(1) \\
\end{array}$ \\
\hline \multicolumn{10}{|l|}{ Noodles } \\
\hline Control & $2(10)$ & $2(10)$ & $14(70)$ & - & - & $2(10)$ & - & - & - \\
\hline \multicolumn{10}{|l|}{$\begin{array}{l}\text { Supple } \\
\text { mented }\end{array}$} \\
\hline $2 \%$ & $2(10)$ & $4(10)$ & $10(70)$ & $2(5)$ & - & $2(5)$ & - & - & - \\
\hline $4 \%$ & - & $2(10)$ & $10(50)$ & $8(40)$ & - & - & - & - & - \\
\hline $6 \%$ & - & - & $16(80)$ & $4(20)$ & - & - & - & - & - \\
\hline $8 \%$ & - & - & $5(25)$ & $10(50)$ & $5(25)$ & - & - & - & - \\
\hline \multicolumn{10}{|l|}{$\begin{array}{l}\text { Macron } \\
\text { i }\end{array}$} \\
\hline Control & $2(10)$ & $2(10)$ & $14(70)$ & - & - & $2(10)$ & - & - & - \\
\hline \multicolumn{10}{|l|}{$\begin{array}{l}\text { Supple } \\
\text { mented }\end{array}$} \\
\hline $2 \%$ & $2(10)$ & $4(30)$ & $10(50)$ & $2(10)$ & - & $2(10)$ & - & - & - \\
\hline $4 \%$ & - & $1(5)$ & $14(70)$ & $5(25)$ & - & - & - & - & - \\
\hline $6 \%$ & - & - & $16(80)$ & $2(10)$ & $2(10)$ & - & - & - & \\
\hline $8 \%$ & - & - & $2(20)$ & $10(50)$ & $8(30)$ & - & - & - & - \\
\hline
\end{tabular}

Figures outside parentheses indicate number of respondents

Values in parentheses are percentage

\section{Results and Discussion:-}

\section{Nutritional composition:-}

The results of proximate composition, in vitro digestibility and total lysine are presented in Table 1. Spirulina powder exhibited $5.27 \%$ moisture, it is very good source of highly bioavailable protein i.e $71.90 \%$, fat $1.27 \%$, crude fibre $9.70 \%$ and ash $3.50 \%$. Other workers also reported high amount of protein (65-70\%) in Spirulina powder (Vijayarani et al., 2012; Salmeàn et al., 2015). Spirulina powder had very low carbohydrate content i.e $13.63 \%$ and $353.55 \mathrm{Kcal} / 100 \mathrm{~g}$ energy content. Similarly, Tang and Suler (2011) also reported 17.8\% of carbohydrate and 373 $\mathrm{Kcal} / 100 \mathrm{~g}$ of energy in Spirulina powder. Other workers also reported similar results in Spirulina powder (Vijayarani et al., 2012; Udayasree et al., 2013; Bensehaila et al., 2015).

In vitro protein digestibility of Spirulina powder was $92.59 \%$ which has been reported to be highly digestible. Total lysine content of Spirulina powder was also found very high i.e $5.72 \mathrm{~g} / 16 \mathrm{gN}$ than any other plant foods. Other workers also reported that Spirulina contained $65-71 \%$ protein which was higher than that of soybean and more digestible due to absence of antinutrients such as phytic acid and polyphenols which are known to inhibit the proteolytic enzymes (Tang and Sauter, 2011; Salmeàn et al., 2015).

Dietary fibre and total mineral of Spirulina platensis powder is presented in Table 2. Spirulina powder exhibited very high content of total, soluble and insoluble dietary fibre. The contents were 14.98, 5.52 and 9.46\%, respectively of total, soluble and insoluble dietary fibre. Spirulina contained many folds higher total mineral contents, 620.80 $\mathrm{mg} / 100 \mathrm{~g}$ calcium, $790.42 \mathrm{mg} / 100 \mathrm{~g}$ phosphorus, $285.90 \mathrm{mg} / 100 \mathrm{~g}$ magnesium, $49.50 \mathrm{mg} / 100 \mathrm{~g}$ iron and $3.95 \mathrm{mg} / 100 \mathrm{~g}$ zinc. Among the minerals, phosphorus had the maximum composition followed by calcium, magnesium, iron and zinc (Table 2). Similar results in Spirulina powder were also reported by (Vijayarani et al., 2012; Bensehaila et al., 2015; Ghaly et al., 2015; Salmeàn et al., 2015). Moreira et al., (2013) reported that calcium, sodium and potassium are the major minerals in Spirulina powder. They also reported that iron and calcium are readily absorbed in Spirulina as compared to other plant foods.

Fatty acid profile of Spirulina platensis powder is presented in Table 3. Spirulina powder contained 30.50 and $1.90 \%$ of total fatty acids palmitic and stearic acid (saturated fatty acids) whereas oleic acid (monounsaturated fatty acid) was only $10.60 \%$ of total fatty acids. Spirulina platensiswas found to be very rich source of gamma linolenic acid (GLA) which accounted for $30.00 \%$ of total fatty acids. Two other polyunsaturated fatty acids i.e linoleic acid 
(omega-6) and alpha-linolenic acid (omega-3) were also present in Spirulina powder which were represented only 2.50 and $14.80 \%$ of total fatty acids, respectively. Similar results were also found by (Bensehaila et al., 2015; Ghaly et al., 2015).

\section{Acceptability of developed products:-}

Mean scores of acceptability of biscuits and buns are presented in Table 4. Control biscuits was 'liked moderately' by majority of respondents (70\%) followed by 'liked extremely' (10\%), 'liked very much' (10\%) and 'liked slightly' $(10 \%)$. In case of supplemented biscuits, majority percentage (70, 60 and 70\%) of respondents were 'liked moderately' Spirulina incorporated biscuits up to $6 \%$ levels. Spirulina fortified biscuits up to $6 \%$ level of incorporation were found at par with control biscuits. Whereas, $8 \%$ Spirulina powder incorporated biscuits were found unacceptable by the respondents in terms of their organoleptic characteristics. Hence, only $10 \%$ of the respondents were 'liked moderately' followed by $60 \%$ 'liked slightly' and 30\% 'neither liked nor disliked'.

Similar trend was also observed in case of buns, majority of respondents $(50 \%)$ were 'liked moderately' followed by 'liked very much' and 'liked slightly'. Spirulina supplemented buns at 2, 4 and 6\% level of incorporation were also found at par with control by the majority $(50,50$ and $75 \%$ ) of respondents. Whereas, $8 \%$ Spirulina incorporated buns was 'liked slightly' by $60 \%$ of respondents.

Acceptability scores of control and supplemented noodles and macroni are presented in Table 5. It was found that majority of respondents $(70 \%)$ were 'liked moderately' the wheat based noodles and macroni. Similarly, Spirulina incorporated noodles and macroni up to $6 \%$ level were also found at par with their respective control. Results indicated that 2, 4 and 6\% Spirulina fortified noodles and macroni were 'liked moderately' by majority of the respondents. Whereas, $8 \%$ Spirulina incorporated noodles and macroni were 'liked slightly' by majority (50\%) of respondents followed 'neither liked nor disliked' and 'liked moderately' by 30 and $20 \%$ of the respondents, respectively. Similar results were also reported by other workers in Spirulina supplemented bread, biscuits, muffins and pasta (Fradique et al., 2010; Lemes et al., 2012; Navacchi et al., 2012; Hafsa et al., 2014; Minh, 2014).

\section{Conclusion:-}

It may be concluded from the present study that Spirulina platensis powder exhibited high amount of protein, total lysine, dietary fibre, total minerals, $\alpha$-linolenic and $\gamma$-linolenic acid. Whereas, low amount of carbohydrate and fat was noticed in Spirulina powder. Hence, its incorporation in wheat flour would be advantageous for enhancing the nutritional quality of wheat based products. Spirulina incorporated products up to $6 \%$ level were 'liked moderately' by majority of respondents.

\section{References:-}

1. AOAC. 2000. Official methods of analysis of association of official analytical chemists. Washington, D.C.

2. Bensehaila, S., Doumandji, A., Boutekrabt, L., Manafikhi, H., Peluso, I., Bensehaila, K., kouache, A. and Bensehaila, A. (2015). The nutritional quality of Spirulina platensisof tamenrasset, algeria. African. Journal of Biotechnology, 14(19): 1649-1654.

3. Chen, P.S., Tosibara, T.Y. and Warner, H. (1956). Micro determination of phosphorus. Analitical Chemistry. 28: 1756-1759.

4. Devinamerin, D., Vipanhesh, N.V., Somaraj, S., Sofiaalex. and Prakash, S. (2007) Studies on growth, biochemical contents, antimicrobial activity and food value of Spirulina platensis. Seaweed Res. Utiln. 29: 255261.

5. Fradique, M., Batista, A.P., Nunes, M.C., Gouveia, L., Bandarra, N.M. and Raymundo, A. (2010). Incorporation of Chlorella vulgaris and Spirulina maxima biomass in pasta products. Part 1: Preparation and evaluation. Journal Science Food Agriculture, 90: 1656-1664.

6. Furda, I. (1981). Simultaneous analysis of soluble and insoluble dietary fiber. In: The Analysis of Dietary Fiber in Food. New York: Marcel Dekker: pp. 163-172.

7. Ghaly, A., Hammouda, A. and Hattab., M. (2015). Development and sensory evaluation of Spirulina chocolate chip oatmeal cookies. International Journal of Bioprocess Biotechnological Advancements, 1(2): 6373.

8. Hafsa, Y.A., Amel, D., Samia, S. and Sidahmed, S. (2014). Evaluation of nutritional and sensory properties of bread enriched with Spirulina. Annals. Food Science and Technology. 15(2): 270-275. 
9. Lemes, A.C., Takeuchi, K.P., Carvalho, J.C.M. and Danesi, E.D.G. (2012). Fresh pasta production enriched with Spirulina platensisbiomass. Brazilian Archives of Biology and Technology. 55: 15-25.

10. Lindsey, W.A. and Norwell, M.A. (1969). A new DPTA-TEA soil test for zinc and iron. Agronomy Abstract. 61: 84-89.

11. McCarty, M.F. (2007). Clinical potential of Spirulina as source of phycocyanobilin. Journal of Medl Food, 10: 566-570.

12. Mertz, E.T., Kireis, A.W. and Sxtell, J.D. (1983). In vitro digestibility of protein in major food cereals. Feed Process. 32(5): 6029.

13. Mertz, E.T., Jambunathan, R. and Misra, P.S. (1975). In: Protein Quality. Agricultural Research Bull. 70: Purdue. University, USA. P.11

14. Minh, N.P. (2014). Effect of Saccharomyces cerevisiae, Spirulina and preservative supplementation to sweet bread quality in bakery. International Journal of Multidisciplinary Research and Development 1(4): 36-44.

15. Moorehead, K., Capelli, B. and Cysewski, G.R. (2011). Spirulina nature's super food. $3^{\text {rd }}$ Cyanotech corporation, Kailua-kona, Hawaii.

16. Moreira, L.M., Ribeiro, A.C., Duarte, F.A., Morais, M.G. and Soares, L.A.S. (2013). Spirulina platensisbiomass cultivated in Southern Brazil as a source of essential minerals and other nutrients. African Journal of Food Science, 7(12): 451-455.

17. Navacchi, M.F.P., Carvalho, J.C.M., Takeuchi, K.P. and Danesi, E.D.G. (2012). Development of cassava cake enriched with its own bran and Spirulina platensis. Acta. Scientiarum Technology. 34(4): 465-472.

18. Paul, A.A. and Southgate, A.D. (1979). The composition of food. $4^{\text {th }}$ Edition, Elsevier North, Holland Biomedical Press, Amestrdam.

19. Salmeán, G.G., Castillo, L.F. and Cevallos, G.C. (2015). Nutritional and toxicological aspects of Spirulina (Arthrospira). Nutr Hosp. 32(1): 34-40.

20. Tang, G. and Suter, P.M. (2011). Vitamin A, nutrition and health values of algae: Spirulina, chlorella and dunaliella. Journal of Pharma and Nutrition Sciences, 1(2): 111-118.

21. Udayasree, V., Manjula, K. and Sowjanya, M. (2013). Effect of Spirulina as a nutritional supplement in malnourished children. International Journal of Scientific Research, 2: 2277-8179.

22. Vasudev, S., Yadava, D.K., Malik, D., Tanwar, R.S. and Prabhu, K.V. (2008). A simplified method for fatty acid analysis of oilseeds. Division of Genetics; Division of Agricultural Chemicals, Indian Agricultural Research institute, New Delhi-110 012.

23. Vijayarani, D., Ponnalaghu, S. and Rajathivya, J. (2012). Development of value added extruded product using Spirulina. International Journal of Health Sciences Research, 2(4): 42-47. 